\title{
Digestibilities of casein and soya-bean protein in relation to their effects on serum cholesterol in rabbits
}

\author{
By CHRISTOPHER J. H. WOODWARD* AND KENNETH K. CARROLL \\ Department of Biochemistry, University of Western Ontario, London, \\ Ontario N6A 5C1, Canada
}

(Received 9 April 1984 - Accepted 29 March 1985)

\begin{abstract}
1. Diets containing isolated soya-bean protein induce lower levels of serum cholesterol in animals than diets containing casein. Experiments were conducted to investigate whether differences in digestibility of the proteins might explain this effect.

2. At $\mathrm{pH} 8$ with pancreatic enzymes or intestinal peptidase, soya-bean protein was hydrolysed in vitro much less rapidly than casein. However, with pepsin $(E C 3.4 .23 .1)$ at acid $\mathrm{pH}$, soya-bean protein was hydrolysed more rapidly than casein.

3. These differences in digestibility may be due to $\mathrm{pH}$-dependent changes in solubility of the proteins. Casein and soya-bean protein were most soluble at alkaline and acid $\mathrm{pH}$ respectively.

4. Heat treatment of the proteins resulted in lower solubilities and digestibilities. Sonication of soya-bean protein at $\mathrm{pH} 7.8$ increased solubility but only slightly raised digestibility.

5 . When fed to rabbits, enzymically hydrolysed soya-bean protein induced a $2 \cdot 3$-fold higher concentration of serum cholesterol than did intact soya-bean protein. The hypocholesterolaemic effect of soya-bean protein may be partly attributable to its low solubility and digestibility at alkaline $\mathrm{pH}$.
\end{abstract}

Dietary plant proteins induce lower levels of serum cholesterol than do animal proteins (Carroll, 1982; Gibney \& Kritchevsky, 1983). This difference mainly reflects alterations in the low-density-lipoprotein fraction, and eventually results in divergent degrees of atherosclerosis.

One characteristic of the proteins which appears to influence serum cholesterol concentration is their amino acid composition. It is known that mixtures of amino acids resembling animal or plant proteins elicit respectively high and low levels of serum cholesterol (Yadav \& Liener, 1977; Huff \& Carroll, 1980; Nagata et al. 1981). However, attempts to relate specific amino acids to cholesterolaemia and atherogenesis have not produced any consensus (Huff \& Carroll, 1980; Kritchevsky, 1983; West et al. 1983).

There is increasing evidence that, in addition to amino acid composition, the conformation of dietary proteins affects serum cholesterol. Thus intact plant proteins are more hypocholesterolaemic than are amino acid mixtures of the same composition (Yadav \& Liener, 1977; Huff \& Carroll, 1980; Nagata et al. 1981). Moreover, amino acid supplementation of casein and soya-bean protein, carried out so as to reverse overall amino acid composition, did not substantially modify their effects on plasma cholesterol concentration (Huff \& Carroll, 1980). Finally, diets having the same overall amino acid composition, but containing different proteins and amino acids, gave dissimilar concentrations of serum cholesterol (Hermus et al. 1979).

The digestibility of dietary protein is a property which may affect cholesterol levels (Hufff \& Carroll, 1980; Carroll \& Woodward, 1982). The present experiments were designed to test this hypothesis. The digestibilities of casein and soya-bean protein were studied initially in vitro, and subsequently an experiment was carried out in vivo.

* Present address: Department of Nutrition, Queen Elizabeth College, Campden Hill Road, London W8 7AH. 


\section{MATERIALS AND METHODS}

\section{Chemicals}

Pancreatin $1 \mathrm{X}$ (hog pancreas), pepsin 1-10,000 (hog stomach mucosa, EC 3.4.23.1), peptidase (hog intestine, partially purified), $\alpha$-chymotrypsin (beef pancreas, 45 units $/ \mathrm{mg}$, $E C$ 3.4.21.1) and trypsin (beef pancreas, 180 units $/ \mathrm{mg}, E C 3.4 .21$.4) were purchased from ICN Pharmaceuticals, Life Sciences Group, Cleveland, OH. Sephadex G 25-150, bovine serum albumin, insulin A-chain and bacitracin were from Sigma Chemical Co., St Louis, MO. Other chemicals were supplied by Fisher Scientific Co., Fair Lawn, NJ.

\section{Dietary constituents}

Supro 610 soya-bean-protein isolate was provided by the Ralston Purina Co. Inc., St Louis, MO. High-nitrogen casein was obtained from United States Biochemical Corporation, Cleveland, OH. Hydrolysed soya-bean protein, Soy Peptone Type III, came from Sigma Chemical Co. The manufacturer's analysis showed that it contained $(\mathrm{g} / \mathrm{kg}): 135$ total $\mathrm{N}$ and 63 amino-N. Vitamins and salt mixture (Phillips \& Hart, (1935), salt mixture IV plus cobalt) were purchased from ICN Pharmaceuticals. Glucose monohydrate was supplied by Teklad Test Diets, Madison, WI, and Celluflour by Chicago Dietetic Supply House, Chicago, IL.

\section{Digestibility tests at fixed $\mathrm{pH}$}

The digestibilities of casein and soya-bean protein were measured initially by the decrease in $\mathrm{pH}$ due to peptide-bond hydrolysis. The procedure was modified from that of $\mathrm{Hsu}$ et al. (1977). Pancreatin suspension $(3.0 \mathrm{mg} / \mathrm{ml}$ in water) was adjusted to $\mathrm{pH} 8.0 \mathrm{using}$ dilute hydrochloric acid and sodium hydroxide, and centrifuged at $1200 \mathrm{~g}$ for $10 \mathrm{~min}$. Supernatant fraction $(1 \mathrm{ml})$ was mixed with $10 \mathrm{ml}$ protein solution $(3.1 \mathrm{mg} / \mathrm{ml}$ in water; previously adjusted to $\mathrm{pH} 8 \cdot 0$ ). The $\mathrm{pH}$ was followed for $6 \mathrm{~min}$ at room temperature. For studies with purified enzymes, $1.6 \mathrm{mg}$ trypsin, $3.0 \mathrm{mg}$ chymotrypsin or $1.2 \mathrm{mg}$ peptidase in $1 \mathrm{ml}$ water were added to the protein solution, and the $\mathrm{pH}$ was followed as before.

The buffering capacities of casein and soya-bean protein were measured by adjusting protein suspensions $(125 \mathrm{mg} / 50 \mathrm{ml}$ water $)$ to $\mathrm{pH} 8.0$ and then titrating to $\mathrm{pH} 6.4$ with dilute $\mathrm{HCl}$.

The validity of results given by $\mathrm{pH}$ readings was verified by determination of the low-molecular-weight trichloroacetic acid (TCA)-soluble peptides before and after hydrolysis. Incubations were performed as described previously, except that $0 \cdot 1 \mathrm{M}$-boric acid$\mathrm{NaOH}$ buffer, $\mathrm{pH} 7 \cdot 8$, was used in place of water. Portions of the hydrolysate were taken at intervals and mixed with TCA solution ( $100 \mathrm{~g} / 1)$. After centrifugation at $1200 \mathrm{~g}$ for $10 \mathrm{~min}$, the protein concentration of the supernatant fraction was measured by the method of Lowry et al. (1951). Bovine serum albumin was used as standard.

Digestibility by pepsin was measured as the accumulation of TCA-soluble peptides during incubation of casein or soya-bean protein suspension $(2.5 \mathrm{mg} / \mathrm{ml} \mathrm{in} 0.1 \mathrm{M}-\mathrm{HCl})$ with $100 \mu \mathrm{g}$ enzyme $/ \mathrm{ml}$. TCA-soluble peptides were determined as described previously. For all incubations, the components were mixed at room temperature using either a magnetic stirrer or metabolic shaker.

\section{Solubility and digestibility at different $\mathrm{pH}$ values}

Studies over the $\mathrm{pH}$ range $2 \cdot 6-7.6$ were carried out in $0.1 \mathrm{M}$-citric acid-sodium hydrogen phosphate buffer. Protein $(2.5 \mathrm{mg} / \mathrm{ml})$ was suspended in the buffer using a Teflon-and-glass homogenizer. Solubility was arbitrarily defined as the protein concentration of the supernatant fraction after centrifugation of a portion at $1200 \mathrm{~g}$ for $10 \mathrm{~min}$.

The remainder of the suspension was incubated with enzyme for $10 \mathrm{~min}$ at room temperature. Digestibility was defined as the increase in TCA-soluble peptides over this 
Table 1. Composition of semi-purified diets containing intact or hydrolysed soya-bean protein

\begin{tabular}{ll}
\hline \hline Ingredient* & $\mathrm{g} / \mathbf{k g}$ \\
\hline Intact or hydrolysed soya-bean protein & 250 \\
Glucose & 600 \\
Celluflour & 50 \\
Salt mixture & 40 \\
Molasses (500 ml/l water) & 30 \\
Water-soluble vitamins $\dagger$ & 10 \\
Fat-soluble vitamins (in maize oil) $\ddagger$ & 10 \\
L-Lysine hydrochloride & 5 \\
L-Methionine & 5 \\
\hline \hline
\end{tabular}

* Molasses and maize oil were obtained locally; origins of the other ingredients are given on p. 356.

$\dagger$ Providing (mg/kg diet): thiamin hydrochloride 15.0 , pyridoxine hydrochloride $37 \cdot 5$, biotin 0.3 , myo-inositol 150 , riboflavin 15 , nicotinic acid 190 , calcium pantothenate 80 , folic acid $3 \cdot 0$, choline chloride 1500 .

$\ddagger$ Providing (/ $\mathrm{kg}$ diet) : retinyl acetate $0.7 \mathrm{mg}, \alpha$-tocopheryl acetate $110 \mathrm{mg}$, menadione $30 \mathrm{mg}$, cholecalciferol $25 \mu \mathrm{g}$.

interval. For studies at $\mathrm{pH} 5 \cdot 6-7 \cdot 6$, pancreatin suspension $(10 \mathrm{mg} / \mathrm{ml})$ was centrifuged and $1 \mathrm{ml}$ supernatant fraction was added to $10 \mathrm{ml}$ protein suspension. For incubations at $\mathrm{pH}$ $2 \cdot 6-4 \cdot 6,100 \mu 1$ pepsin solution $(10 \mathrm{mg} / \mathrm{ml} 0 \cdot 1 \mathrm{M}-\mathrm{HCl})$ were added.

\section{Heating and sonication of proteins}

For studies of heated proteins, casein and soya-bean protein were autoclaved at $138 \mathrm{kPa}$ (20 psi) for $1 \mathrm{~h}$. Digestibilities and solubilities over the $\mathrm{pH}$ range 2.6-7.6 were assayed as described previously. For experiments involving sonication, protein suspensions $(2.5 \mathrm{mg} / \mathrm{ml})$ in $0.1 \mathrm{M}-\mathrm{HBO}_{3}-\mathrm{NaOH}$ buffer, $\mathrm{pH} 7 \cdot 8$, were treated using a W 350 Sonifier Branson Sonic Power Co., Danbury, CT) on setting 5. Protein solubilities and digestibilities using pancreatin were determined as described previously.

\section{In vivo experiment}

Intact and enzymically hydrolysed soya-bean proteins (Supro 610 and Sigma Soy Peptone Type III) were characterized by chromatography on a column of Sephadex G25-150 $(500 \times 25 \mathrm{~mm}$ ). Samples of approximately $30 \mathrm{mg}$ protein were suspended in $5 \mathrm{ml} 0.1 \mathrm{M}-$ potassium dihydrogen phosphate-potassium hydrogen phosphate buffer, $\mathrm{pH} 7.8$. The soya-bean protein suspension was centrifuged at $10000 \mathrm{~g}$ for $30 \mathrm{~min}$ before loading the supernatant fraction on the column. The peptone was fully soluble. Protein concentration in the eluate was measured by monitoring absorbance at $280 \mathrm{~nm}$. The column was standardized with bovine serum albumin, insulin A-chain, bacitracin and L-tryptophan. Void volume was measured using Dextran Blue.

Male, New Zealand White rabbits were purchased at a weight of $1.5 \mathrm{~kg}$ and housed

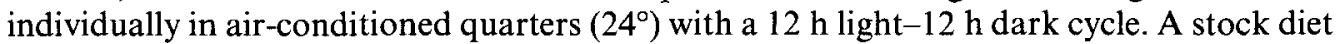
(Master Feed Rabbit Pellets, Maple Leaf Mills, Toronto, Ont.) and tap water were available ad lib. At $10 \mathrm{~d}$ after arrival, six animals were transferred to each of two semi-purified diets, containing intact or hydrolysed soya-bean protein respectively (Table 1). The diets were made up weekly, stored at $4^{\circ}$ and provided $a d l i b$.

Blood samples were obtained by venesection of the marginal ear vein before the diet change, and 2 and 4 weeks thereafter. After allowing the blood to clot, serum was separated by centrifugation at $1200 \mathrm{~g}$ for $15 \mathrm{~min}$. Cholesterol was extracted (Mann, 1961) and 

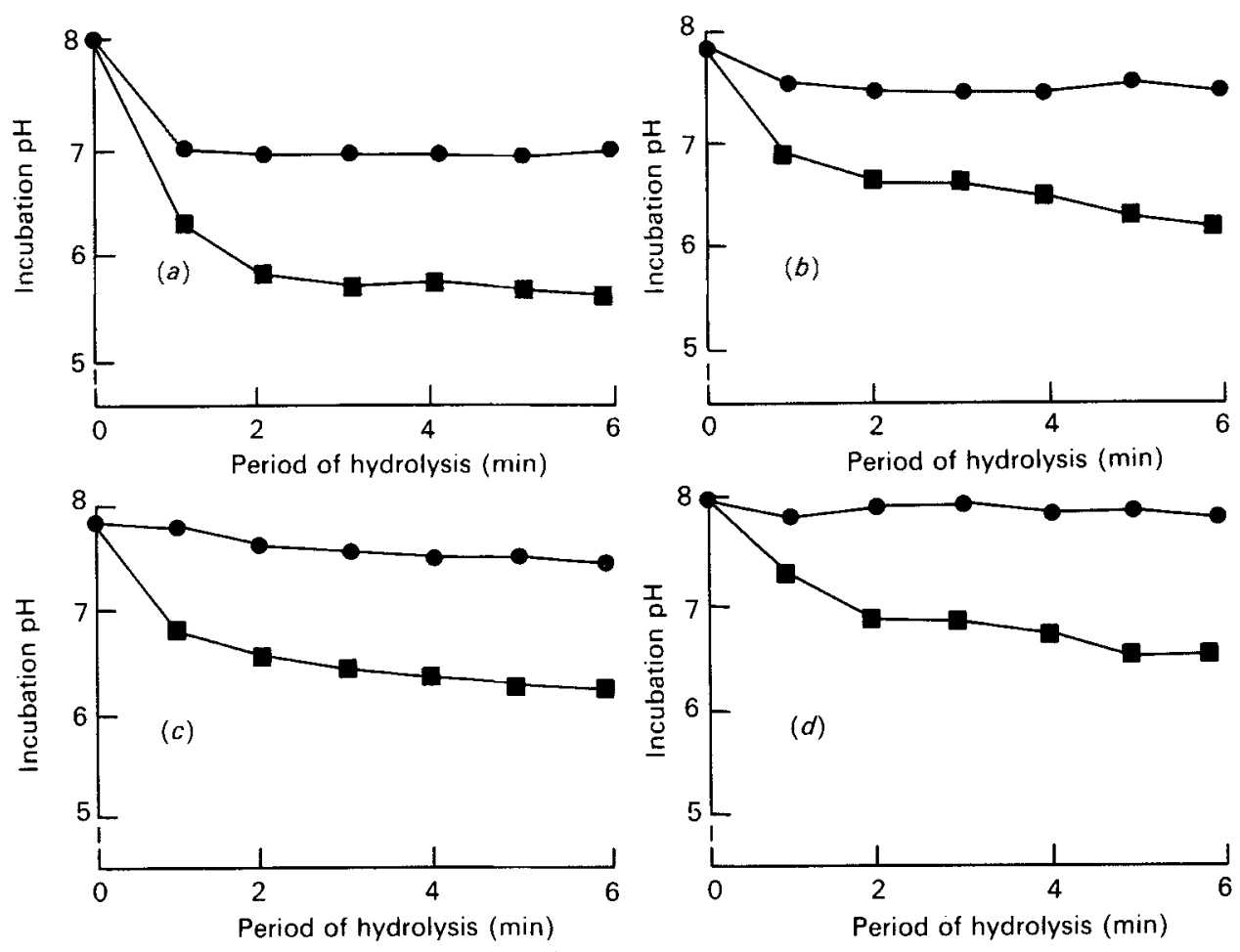

Fig. 1. In vitro digestibilities of casein ( $($ ) and soya-bean protein $(\odot)$ solutions measured as the decrease in $\mathrm{pH}$ after adding enzyme. Incubations with $(a)$ pancreatin, $(b)$ trypsin $(E C 3.4 .21 .4)$, (c) chymotrypsin $(E C$ 3.4.21.1) and $(d)$ peptidase. Points are means of duplicate incubations. Pooled standard errors were: pancreatin $0.035 \mathrm{pH}$ units, trypsin 0.102 units, chymotrypsin 0.097 units and peptidase 0.101 units.

determined colorimetrically (Zlatkis \& Zak, 1969). At the end of the experiment, serum pools were prepared and pre-stained with Sudan Black before lipoprotein analysis by density-gradient centrifugation (Terpstra et al. 1981). Cholesterol was determined in each visible lipoprotein fraction by the methods referred to previously.

RESULTS

Digestibility tests at fixed $p H$

In initial experiments, digestibility was measured from $\mathrm{pH}$ decreases resulting from the release of amino acids during hydrolysis. After all incubations, the $\mathrm{pH}$ of casein hydrolysates was at least 1.3 units lower than the corresponding values for soya-bean protein (Fig. 1). Comparing the different enzymes, greater $\mathrm{pH}$ decreases were observed with crude pancreatin (Fig. 1 (a)) than with the purified preparations of trypsin, chymotrypsin and peptidase (Fig. $1(b-d))$.

Measurements were taken to check whether differences in buffering capacity rather than digestibility between the proteins might affect the previously quoted results. In order to decrease the $\mathrm{pH}$ of solutions containing $125 \mathrm{mg}$ casein or soya-bean protein from $\mathrm{pH} 8.0$ to $\mathrm{pH} 6.4,6.5$ and $14.8 \mathrm{ml}$ dilute $\mathrm{HCl}$ were required respectively. Because of the different buffer capacities indicated by these results, further studies of digestibility were made using another technique.

Fig. 2(a) shows the amounts of TCA-soluble peptides released from the substrate proteins 

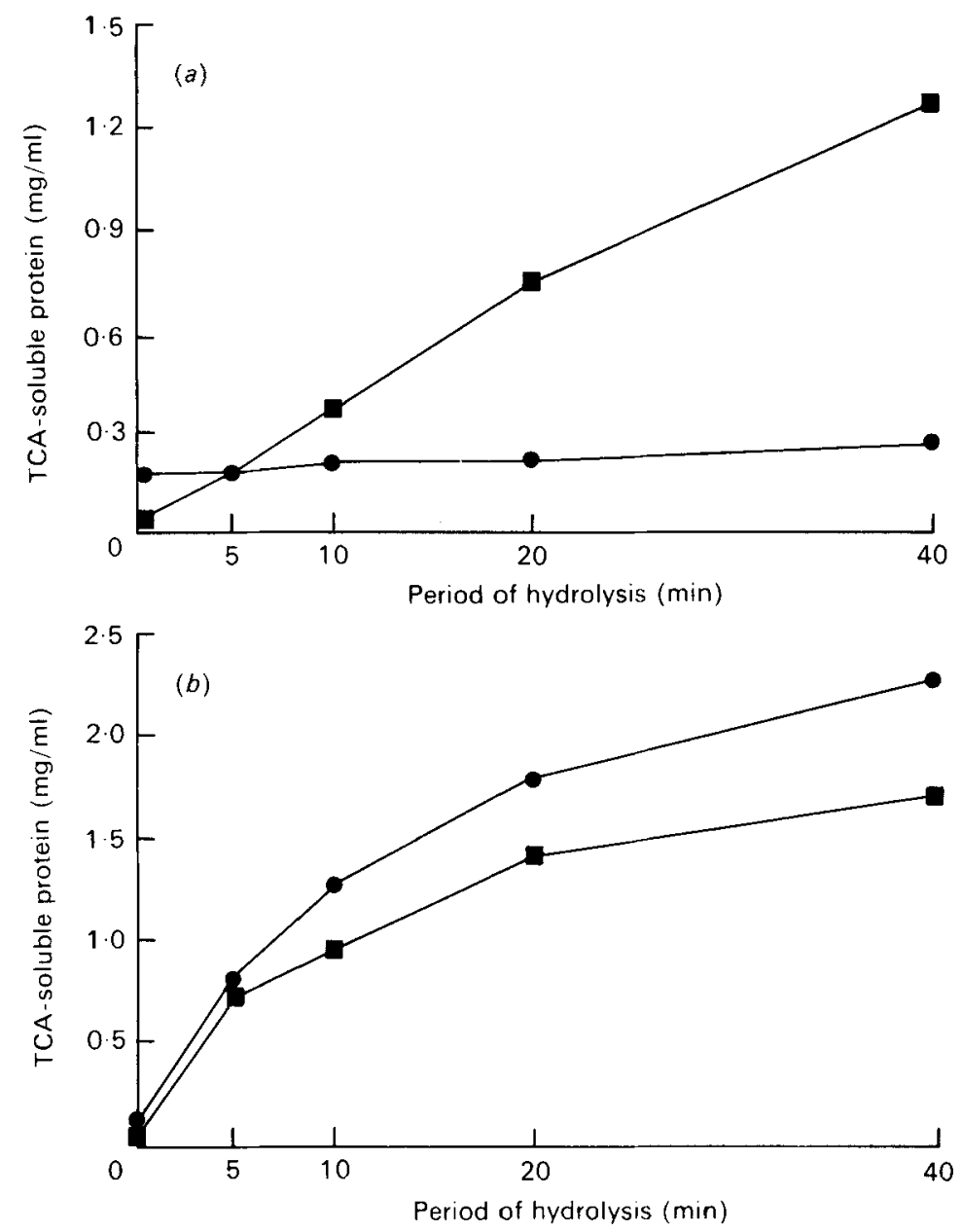

Fig. 2. In vitro digestibilities of casein $(\boldsymbol{D})$ and soya-bean protein $(\bullet)$ solutions measured as the accumulation of trichloroacetic acid (TCA)-soluble protein after adding enzyme. Incubations with $(a)$ pancreatin in $0.1 \mathrm{M}$-boric acid-sodium hydroxide buffer, $\mathrm{pH} 7.8$, and $(b)$ pepsin $(E C$ 3.4.23.1) in 0.1 M-hydrochloric acid. Points in $(a)$ are means of duplicate samples with a pooled standard error of $0.014 \mathrm{mg} / \mathrm{ml} ;(b)$ shows a typical example of three replicates.

by pancreatin. At all time-points after the initial reading, TCA-soluble peptide levels were higher for casein than for soya-bean protein. The initial reading at 1 min was slightly higher for soya-bean protein; a similar difference was noted in subsequent experiments where the initial reading was taken before hydrolysis.

Incubations with pepsin revealed different digestibilities from those found at alkaline $\mathrm{pH}$ (Fig. 2(b)). Both substrates were readily digested, soya-bean protein showing slightly more rapid hydrolysis than casein. After $40 \mathrm{~min}$ incubation, both proteins were over $60 \%$ digested into TCA-soluble peptides.

Solubility and digestibility at different $\mathrm{pH}$ values

During the previously described incubations, visual differences in protein solubility were apparent. Casein seemed more soluble at alkaline than at acid $\mathrm{pH}$, while the converse was 

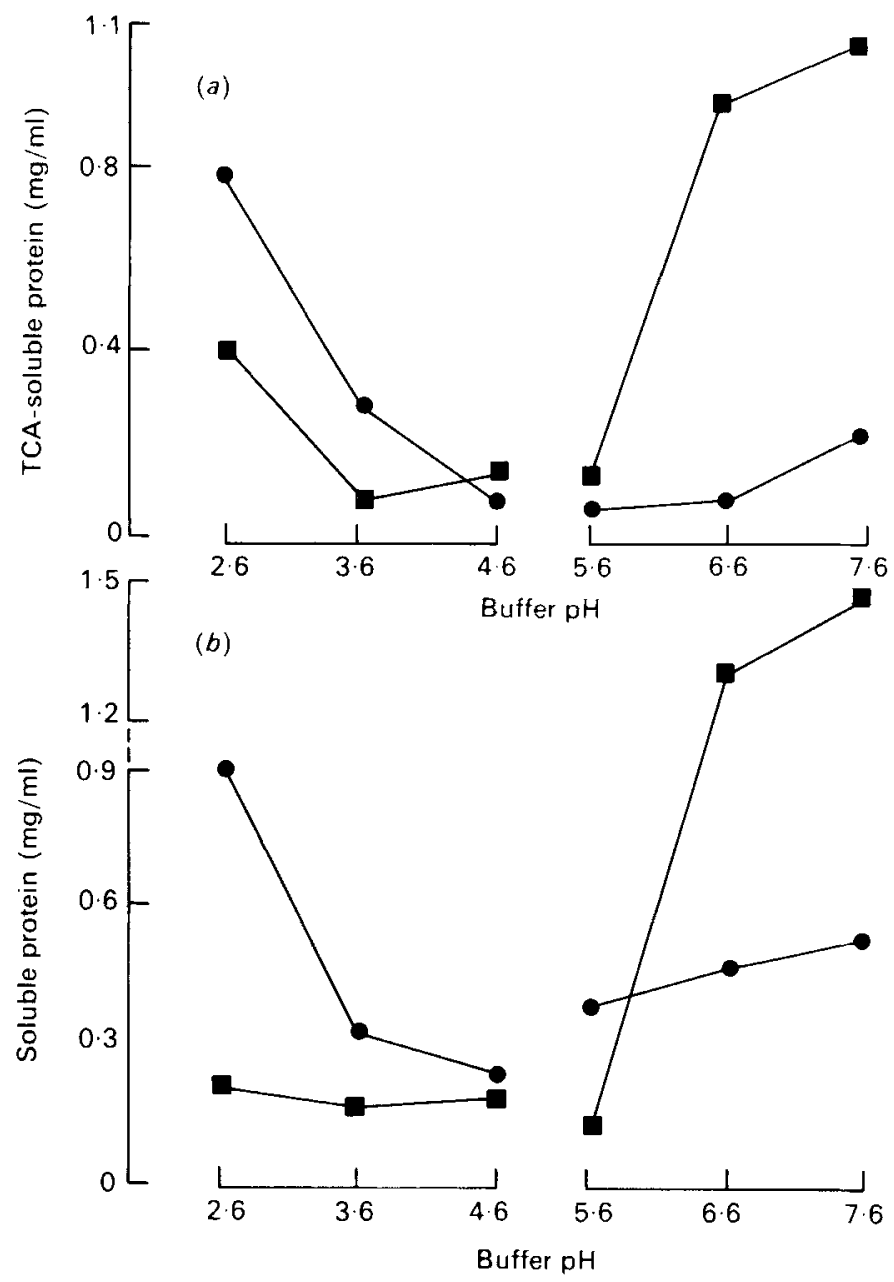

Fig. 3. In vitro digestibilities and solubilities of casein ( $\square$ ) and soya-bean protein (O) in $0 \cdot 1 \mathrm{M}$-citric acid-sodium hydrogen phosphate buffer at various $\mathrm{pH}$ values. (a) Digestibility, measured as accumulation of trichloroacetic acid (TCA)-soluble protein during $10 \mathrm{~min}$ incubation with pepsin $(E C 3.4 .23 .1)(\mathrm{pH}$

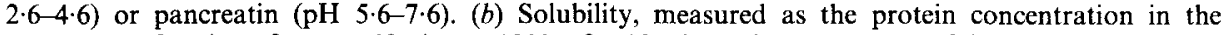
supernatant fraction after centrifuging at $1200 \mathrm{~g}$ for $10 \mathrm{~min}$. Points are means of duplicate incubations, with pooled standard errors of $0.014 \mathrm{mg} / \mathrm{ml}$ and $0.040 \mathrm{mg} / \mathrm{ml}$ for digestibility and solubility respectively.

true for soya-bean protein. The possible influence of this factor on digestibility in vitro was therefore investigated.

At $\mathrm{pH}$ 6.6-7.6, casein was more readily digested than soya-bean protein by pancreatin (Fig. 3(a)) and its solubility was also substantially higher (Fig. 3(b)). Conversely, at $\mathrm{pH} 2 \cdot 6-3 \cdot 6$, soya-bean protein was more readily digested by pepsin and was more soluble than casein. Both proteins had isoelectric points between $\mathrm{pH} 4.6$ and 5.6 , where both digestibility and solubility were at a minimum. Changes in the relative digestibilities of the two proteins thus paralleled their solubilities. In addition, for each protein individually, patterns of digestibility and solubility were comparable. Only pancreatin digestibility of soya-bean protein was lower than expected on the basis of its solubility. 


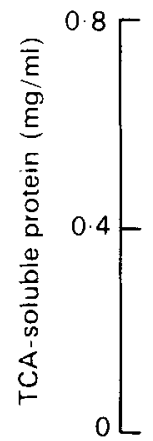

(a)
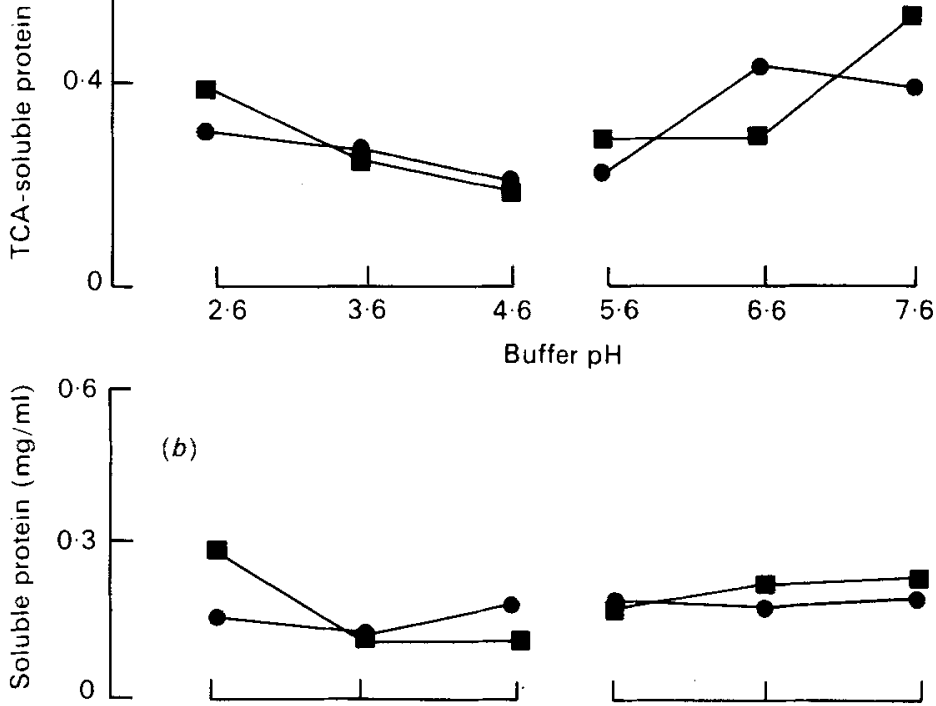

(b)
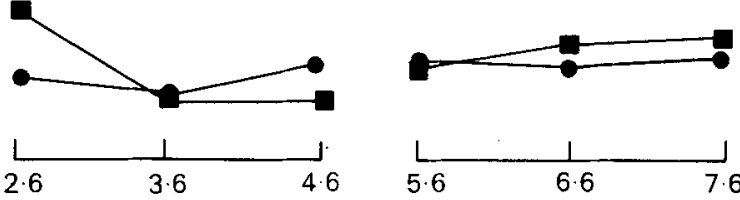

Buffer $\mathrm{pH}$

Fig. 4. In vitro digestibilities and solubilities of casein $(\boldsymbol{\square})$ and soya-bean protein $(\bullet)$ after autoclaving for 1 h. (a) Digestibility and $(b)$ solubility. For details, see Fig. 3 and p. 356. Two replicate experiments were carried out at $\mathrm{pH} 2 \cdot 6-4 \cdot 6$ only. TCA, trichloroacetic acid.

Table 2. Effects of sonication on solubilities and digestibilities of casein and soya-bean protein*

\begin{tabular}{llccc}
\hline \hline & & \multicolumn{4}{c}{ Period of sonication (min) } \\
\cline { 2 - 5 } Protein & 0 & 1 & 5 & 10 \\
\hline & & Solubility (mg protein $/ \mathrm{ml})$ \\
Soya-bean protein & 0.62 & 1.15 & 1.38 & 1.35 \\
Casein & 1.35 & 1.46 & 1.52 & 1.48 \\
& Digestibility (mg TCA-soluble protein $/ \mathrm{ml})$ \\
Soya-bean protein & 0.67 & - & 0.74 & - \\
Casein & 1.59 & - & 1.75 & - \\
\hline
\end{tabular}

TCA, trichloroacetic acid.

* Results are means of duplicate incubations with pooled standard errors of $0.067 \mathrm{mg} / \mathrm{ml}$ and $0.022 \mathrm{mg} / \mathrm{ml}$ for solubility and digestibility respectively.

\section{Effects of heating and sonication}

After heat treatment, there were no consistent differences between casein and soya-bean protein for either digestibility or solubility (Fig. 4). Compared with unheated proteins (Fig. 3), heat treatment tended to decrease both digestibility and solubility especially for casein at alkaline $\mathrm{pH}$ and soya-bean protein at acid $\mathrm{pH}$ respectively.

Sonication of the proteins at $\mathrm{pH} 7 \cdot 8$ increased the solubility of soya-bean protein more than that of casein (Table 2). When digestibility using pancreatin was measured after $5 \mathrm{~min}$ 

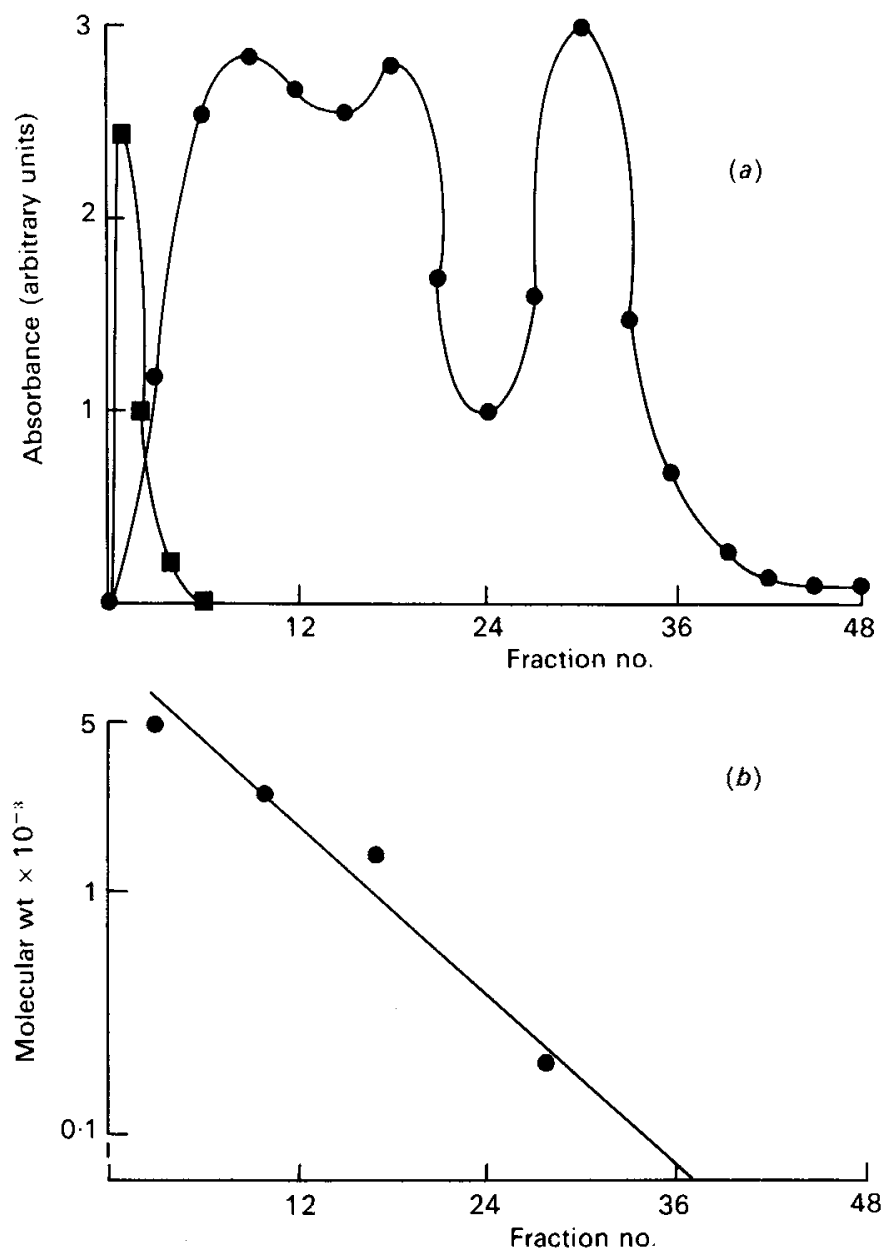

Fig. 5. Column chromatography of intact ( $\mathbf{0})$ and hydrolysed (O) soya-bean protein, using Sephadex G25-150 and 0.1 M-potassium dihydrogen phosphate-dipotassium hydrogen phosphate buffer, pH 7.8. (a) Elution profile. (b) Standard line obtained by plotting elution volume v. log (molecular weight) for three calibration proteins and L-tryptophan. The diagram shows typical results out of at least two replicates for each protein preparation.

sonication and compared with untreated samples, increases of only 8 and $12 \%$ were noted for soya-bean protein and casein respectively.

\section{In vivo experiment}

Soya-bean protein and hydrolysed soya-bean protein were characterized by Sephadex column chromatography before examining their effects in rabbits. The chromatogram of the hydrolysate showed three peaks, while soya-bean protein eluted in a single peak within the void volume (Fig. $5(a)$ ). The plot of $\log$ (molecular weight) v. elution volume for the standard proteins produced a straight line (Fig. $5(b)$ ). Using this, the molecular weights of peaks in the hydrolysate chromatogram were calculated as 2000, 600 and 350 approximately. 
Table 3. Growth and serum cholesterol concentrations of rabbits given intact or hydrolysed soya-bean protein

(Means with their standard errors for six animals per group)

\begin{tabular}{|c|c|c|c|c|c|c|c|c|c|c|}
\hline \multirow{3}{*}{$\begin{array}{l}\text { Week... } \\
\text { Group }\end{array}$} & \multicolumn{4}{|c|}{ Body-wt (g) } & \multicolumn{6}{|c|}{ Serum cholesterol concentration $(\mathrm{mmol} / \mathrm{l})$} \\
\hline & \multicolumn{2}{|l|}{0} & \multicolumn{2}{|c|}{4} & \multicolumn{2}{|c|}{0} & \multicolumn{2}{|c|}{2} & \multicolumn{2}{|c|}{4} \\
\hline & Mean & SE & Mean & $\mathrm{SE}$ & Mean & SE & Mean & $\mathrm{SE}$ & Mean & $\mathrm{SE}$ \\
\hline Hydrolysate & 1722 & 42 & 2235 & 52 & 1.62 & $0 \cdot 12$ & $2 \cdot 42$ & $0 \cdot 22$ & $2 \cdot 81$ & 0.40 \\
\hline Intact & 1752 & 88 & 2497 & 81 & $1 \cdot 60$ & $0 \cdot 15$ & 1.46 & $0 \cdot 27$ & $1 \cdot 17$ & 0.29 \\
\hline \multicolumn{11}{|l|}{$\begin{array}{l}\text { Statistical } \\
\text { significance of } \\
\text { difference }\end{array}$} \\
\hline (Student's $t$ test): $P$ & \multicolumn{2}{|c|}{ NS } & \multicolumn{2}{|c|}{$<0.05$} & \multicolumn{2}{|c|}{ NS } & \multicolumn{2}{|c|}{$<0.02$} & \multicolumn{2}{|c|}{$<0.01$} \\
\hline
\end{tabular}

NS, not significant.

Animals given hydrolysate gained slightly less weight than did those receiving soya-bean protein (Table 3). Initial levels of serum cholesterol were similar for the two groups. Cholesterol concentration increased on feeding hydrolysate but was reduced in animals given soya-bean protein (Table 3 ). At 4 weeks, rabbits given hydrolysate had a $2 \cdot 3$-fold higher cholesterol level than did those given soya-bean protein. Most of this difference was due to the low-density-lipoprotein fraction $(1.01<$ density $<1.05)$. Cholesterol concentrations in this fraction were 1.53 and $0.54 \mathrm{mmol} / 1$ for rabbits fed on hydrolysate and soya-bean protein respectively. Cholesterol levels in very-low-density and high-density lipoproteins were increased to a lesser extent in animals fed on hydrolysate (values not shown).

\section{DISCUSSION}

Initial digestibility tests using the $\mathrm{pH}$ technique showed that soya-bean protein was less rapidly hydrolysed than casein by pancreatic or intestinal enzymes. The difference in final $\mathrm{pH}$ between soya-bean protein and casein digests was rather greater than that found by Hsu et al. (1977). This discrepancy might be explained by differing buffer capacities of the proteins used in the two studies. Hsu et al. (1977) concluded that differences in buffer capacity did not affect the method. However, in our study Supro 610 had a substantially greater buffering action than casein, suggesting that this property should be taken into account.

Further experiments were carried out using a TCA precipitation technique, which measures the hydrolysis of proteins to peptides of molecular weight less than about 10000 daltons. Free amino acids and small peptides, which are the absorbable end-products of protein digestion, are not differentiated by this technique from peptides of molecular weight up to 10000 daltons. The results showed that, with pancreatin, catabolism to medium-weight peptides proceeded more readily with casein than with soya-bean protein. However, at acid $\mathrm{pH}$ with pepsin, both proteins were readily digested. This latter finding is consistent with previous reports that soya-bean protein is quite susceptible to pepsin digestion (Steinhart \& Kirchgessner, 1974; Amiot et al. 1981). To our knowledge, there is no previous study on digestibility of soya-bean protein using pancreatic enzymes alone. However, Camus et al. (1973) showed that vegetable proteins were generally less readily digested by trypsin compared with proteins of animal origin. 
The incubations at different $\mathrm{pH}$ values suggested a causal relation between solubility and digestibility. Casein and soya-bean protein were most soluble at high and low $\mathrm{pH}$ respectively. The solubility patterns of casein and soya-bean protein are exploited in their isolation, which involves selective precipitation at $\mathrm{pH} 4 \cdot 0-4 \cdot 2$ and $\mathrm{pH} 4 \cdot 6$ respectively (Brunner, 1977; Wolf, 1977). Precipitated proteins may be less digestible because they are physically removed from enzyme molecules. In interpreting the present results, it should be noted that low digestibilities at intermediate $\mathrm{pH}$ may have been due partly to the enzymes operating far from their optimal $\mathrm{pH}$.

It is well known that heat damage reduces the nutritive value of proteins (Friedman, 1977; Vachon et al. 1982). The mechanism is thought to involve the reaction of amino acids to form products that are resistant to digestion and absorption. In the present experiments, heated proteins displayed both low digestibility and solubility, confirming the relation between these properties. Reduction of solubility could thus contribute to the lowering of nutritional value found after heat treatment.

In contrast with the previous results, sonication produced a large increase in solubility of soya-bean protein, but only a small change in digestibility. Sonication is known to aggregate soya-bean protein molecules as well as increasing their solubility (Wang, 1981). This could explain why, in this case, the susceptibility to enzymic hydrolysis was not raised. Presumably the energy imparted by sonication allows the molecules to assume a state of lower potential energy, in which hydrophobic amino acid residues in one molecule are shielded from the aqueous medium by similar residues in neighbouring molecules (Tanford, 1978). Wang (1981) found that the soya-bean protein aggregates were more stable at concentrations above $0.8 \mathrm{mg} / \mathrm{ml}$, a range which includes the concentration used in the present study. Sonication promotes aggregation in a number of other circumstances, for example the interaction of immunoglobulins with liposomes (Huang \& Kennel, 1979).

In addition to the considerations of solubility discussed previously, it is possible that trypsin inhibitors might contribute to the low digestibility of soya-bean protein. However, these substances are unlikely to play a major role, since most of the trypsin inhibitor activity in whole soya beans is lost during isolation of the proteins (Anderson et al. 1979). Moreover, when added to a diet containing casein, purified trypsin inhibitor did not significantly affect cholesterol levels in mice, despite a stimulation of pancreatic weight and enzyme content (Roy \& Schneeman, 1981).

Attempts to mimic in vivo digestion, by means of sequential treatment with pepsin and pancreatic enzymes, have shown less (Amiot et al. 1981) or not consistently different (Gauthier et al. 1982) hydrolysis for soya-bean protein compared with casein. Such studies are questionable because the relative contribution of pepsin to proteolysis in vivo is not known. Overall digestibility in vivo, measured as the difference between ingested and faecal $\mathrm{N}$, is relatively high for soya-bean protein (Gillberg, 1977). In this case microbial degradation in the colon may disguise preceding differences in digestibility between proteins. Rats given soya-bean protein have more $\mathrm{N}$ in the small gut than those given casein (Zebrowska, 1968). Moreover, a greater flow of protein to the ileum was noted in pigs given soya-bean protein than in those given casein (Leibholz, 1981). Such evidence suggests that soya-bean protein is indeed relatively slowly digested in vivo.

In the present experiments, hydrolysed soya-bean protein caused a hypercholesterolaemia due to accumulation of cholesterol in low-density lipoproteins. An earlier study showed similar cholesterol levels in rabbits given intact or hydrolysed soya-bean proteins (Huff et al. 1977). This discrepancy might be explained by different degrees of digestion of the hydrolysates during preparation. In the present case, total and free amino-N contents of the hydrolysate were 13.5 and $6.3 \%$ respectively. The ratio, free: total amino- $\mathrm{N}$ is 0.47 , and this is an index of the degree of hydrolysis. The equivalent values for the product used by 
Huff et al. (1977) are 12.7 and $4.7 \%$, giving a ratio of 0.37 . Alternatively, it is possible that the differing weight gains of the two groups in the present study contributed to their divergent cholesterol levels. However, it is unlikely that this factor wholly accounts for the hypercholesterolaemia. Lacombe et al. (1983) found that a $50 \%$ food restriction was necessary to induce a twofold elevation of serum cholesterol concentration in rabbits.

Lefevre \& Schneeman (1982) have previously studied the relation between digestibility and serum cholesterol. They found that heat-treated casein was poorly digested by rats and induced higher levels of cholesterol than untreated protein. A link between low digestibility and reduced serum cholesterol levels, as found here, is supported by experiments in which formaldehyde-treated casein was fed to rabbits (West et al. 1984). Digestibility might affect serum cholesterol concentration by means of delays in the release and absorption of amino acids from the gut (Carroll \& Woodward, 1982). Alternatively, poorly digested proteins may bind bile acids and inhibit reabsorption of the latter from the ileum (Woodward \& West, 1984). Further experiments could usefully evaluate these mechanisms in animals and man (Redgrave, 1984).

Support by the Ontario Heart Foundation is gratefully acknowledged. K. K.C. is a Career Investigator of the Medical Research Council of Canada. C. J.H.W. received a Research Fellowship from the Ontario Heart Foundation. The authors thank Dr L. Savoie, Centre de Recherche en Nutrition, Université Laval, Quebec, for commenting on the manuscript. Supro 610 soya-bean-protein isolate was a kind gift from the Ralston Purina Co.

\section{REFEREN CES}

Amiot, J., Brisson, G. J., Delisle, L., Goulet, G., Savoie, L. \& Jones, J. D. (1981). Nutrition Reports International 24, 513-529.

Anderson, R. L., Rackis, J. J. \& Tallent, W. H. (1979). In Soy Protein and Human Nutrition, pp. 209-233 [H. L. Wilcke, D. T. Hopkins and D. H. Waggle, editors], New York: Academic Press.

Brunner, J. R. (1977). In Food Proteins, pp. 175-208 [J. R. Whitaker and S. R. Tannenbaum, editors]. Westport, CT: Avi.

Camus, M-C., Laporte, J-C. \& Sautier, C. (1973). Annales de Biologie Animale, Biochimie, Biophysique 13, $193-202$.

Carroll, K. K. (1982). Federation Proceedings 41, 2792-2796.

Carroll, K. K. \& Woodward, C. J. H. (1982). In Atherosclerosis: Clinical Evaluation and Therapy, pp. 225-229 [S. Lenzi and G. C. Descovich, editors]. Lancaster: MTP.

Friedman, M. (1977). In Food Proteins, pp. 446-483 [J. R. Whitaker and S. R. Tannenbaum, editors]. Westport, CT: Avi.

Gauthier, S. F., Vachon, C., Jones, J. D. \& Savoie, L. (1982). Journal of Nutrition 112, 1718-1725.

Gibney, M. J. \& Kritchevsky, D. (editors) (1983). In Animal and Vegetable Proteins in Lipid Metabolism and Atherosclerosis. New York: Alan R. Liss.

Gillberg, L. (1977). Nutrition Reports International 16, 603-610.

Hermus, R. J. J., Terpstra, A. H. M. \& Dallinga-Thie, G. M. (1979). Voeding 40, 95-99.

Hsu, H. W., Vavak, D. L., Saterlee, L. D. \& Miller, G. A. (1977). Journal of Food Science 42, $1269-1273$.

Huang, L. \& Kennel, S. J. (1979). Biochemistry 18, 1702-1707.

Huff, M.W. \& Carroll, K. K. (1980). Journal of Nutrition 110, 1676-1685.

Huff, M. W., Hamilton, R. M. G. \& Carroll, K. K. (1977). Atherosclerosis 28, 187-195.

Kritchevsky, D. (1983). Atherosclerosis 48, 209-210.

Lacombe, C., Corraze, G. \& Nibbelink, M. (1983). Lipids 18, 306-312.

Lefevre, M. \& Schneeman, B. O. (1982). Federation Proceedings 41, 720.

L.eibholz, J. (1981). British Journal of Nutrition 46, 59--69.

Lowry, O. H, Rosebrough, N. J., Farr, A. L. \& Randall, R. J. (1951). Journal of Biological Chemistry 193, $265-275$.

Mann, G. V. (1961). Clinical Chemistry 7, 275-284.

Nagata, Y., Tanaka, K. \& Sugano, M. (1981). British Journal of Nutrition 45, 233-241.

Fhillips, P. H. \& Hart, E. B. (1935). Journal of Biological Chemistry 109, 657-663.

Fedgrave, T. G. (1984). Atherosclerosis 52, 349-351.

Fioy, D. M. \& Schneeman, B. O. (1981). Journal of Nutrition 111, 878-885.

Steinhart, H. \& Kirchgessner, M. (1974). Nutrition Abstracts and Reviews 44, 719-720.

T'anford, C. (1978). Science 200, 1012-1018. 
Terpstra, A. H. M., Woodward, C. J. H. \& Sanchez-Muniz, F. J. (1981). Analytical Biochemistry 111, $149-157$.

Vachon, C., Gauthier, S. F., Jones, J. D. \& Savoie, L. (1982). Nutrition Research 2, 675-688.

Wang, L. C. (1981). Journal of Agricultural and Food Chemistry 29, 177-180.

West, C. E., Beynen, A. C., Scholz, K. E., Terpstra, A. H. M., Schutte, J. B., Deuring, K. \& van Gils, L. G. M. (1984). Journal of Nutrition 114, 17-25.

West, C. E., Beynen, A. C., Terpstra, A. H. M., Scholz, K. E., Carroll, K. K. \& Woodward, C. J. H. (1983). Atherosclerosis 46, 253-256.

Wolf, W. J. (1977). In Food Proteins, pp. 291-314 [J. R. Whitaker and S. R. Tannenbaum, editors]. Westport, CT: Avi.

Woodward, C. J. H. \& West, C. E. (1984). Proceedings of the Nutrition Society 43, 63A.

Yadav, N. R. \& Liener, I. E. (1977). Nutrition Reports International 16, 385-389.

Zebrowska, T. (1968). British Journal of Nutrition 22, 483-491.

Zlatkis, A. \& Zak, B. (1969). Analytical Biochemistry 29, 143-148. 